УДК 330.332:656.2(477)

\title{
РОЗРОБКА МЕХІНАЗМУ СОЦІАЛЬНОГО ІНВЕСТУВАННЯ ПАТ «УКРЗАЛІЗНИЦЯ»
}

\author{
Панченко Н.Г., к.е.н., доцент (УкрДУЗТ)
}

Процес соиіального інвестування ПАТ «Укрзалізниця» $е$ динамічним процесом реалізації взаємовідносин між суб'єктами та об'єктами інвестування, який покликаний збалансувати інтереси корпоративного та сочіального секторів економіки. Автором доведено, щзо механізм управління соиіальною інвестиційною діяльністю ПАТ «Укрзалізнищя» охоплює традииійні компоненти системи управління, серед яких планування, аналіз, організація, контроль, оиінка, мотивація соиіальної інвестииійної діяльності. Крім того, включає специфічні набори інструментарію залучення інвестицій, відрізнясться моделями розподілу інвестиційних ресурсів, напрямками активізаиіі інвестииійної діяльності та чинниками забезпечення інвестииійної привабливості. Він визначається як сукупність організаційно-економічних форм і методів, інструментів $i$ важелів дії на соиіальну інвестииійну діяльність, взаємопов'язаних в єдиний механізм, щзо припускає мотивачійне, правове, ресурсне і методичне забезпечення, котрий дозволяє визначити обсяг, структуру, напрями $і$ реалізацію соціальних інвестицій з метою досягнення максимального корисного ефекту $i$ забезпечення стабільної фінансовогосподарської діяльності ПАТ «Укрзалізниия» в найближчій і подальшій перспективі.

Ключові слова: соціальні інвестиції, механізм соціального інвестування, залізничний транспорт, ПАТ «Укрзалізниця», процес соціального інвестування

\section{РАЗРАБОТКА МЕХИНАЗМА СОЦИАЛЬНОГО ИНВЕСТИРОВАНИЯ ПАО «УКРЗАЛИЗНЫЦЯ»}

\section{Панченко Н.Г., к.э.н., доцент (УкрГУЖТ)}

Процесс соииального инвестирования ПАО «Укрзализныия» является динамическим процессом реализации взаимоотномений между субъектами и объектами инвестирования, который призван сбалансировать интересы корпоративного $u$ сочиального секторов экономики. Автором доказано, что механизм управления сочиальной инвестиционной деятельностью ПАО «Укрзализныия» охватывает традиционные компоненты системы управления, среди которых планирование, анализ, организация, контроль, оченка, мотивация сочиильной инвестиционной деятельности. Кроме того, включает специфические наборы инструментария привлечения инвестиций, отличается моделями распределения инвестиционных ресурсов, направлениями активизации инвестищионной деятельности $u$ факторами обеспечения инвестиционной привлекательности. Он определяется как совокупность организационно-экономических форм и методов, инструментов и рычагов воздействия на сочииальную инвестиционную деятельность, взаимосвязанных в единый механизм, предполагающий мотивационное, правовое, ресурсное и методическое обеспечение, позволяющий определить объем, структуру, направления и реализачию сочиальных инвестищий с иелью достижения максимального полезного эффекта и обеспечения стабильной финансово-хозяйственной деятельности ПАО «Укрзализныця» в ближайтей и дальнейтей перспективе.

Ключевые слова: социальные инвестиции, механизм социального инвестирования, жселезнодорожный транспорт, ПАО «Укрзализныця", процесс социального инвестирования

(C) Панченко Н.Г.

Вісник економіки транспорту і промисловості № 64, 2018 


\section{DEVELOPMENT OF MACHINISM SOCIAL INVESTMENT PJSC «UKRZALIZNYTSIA»}

\section{Panchenko N.G., Ph.D. in Economics, associate Professor (USURT)}

The process of social investment of PJSC "Ukrzaliznytsia" is a dynamic process of implementation of relationships between subjects and objects of investment, which is designed to balance the interests of the corporate and social sectors of the economy. The author proves that the mechanism of management of social investment activity of PJSC "Ukrzaliznytsia" covers the traditional components of the management system, including planning, analysis, organization, control, evaluation, motivation of social investment activity. In addition, includes a specific set of targeting tools, different patterns of allocation of investment resources, investment activity and factors providing investment attractiveness. It is defined as a set of organizational and economic forms and methods, tools and levers of influence on social investment activities, interrelated in a single mechanism, involving motivational, legal, resource and methodological support, which allows to determine the volume, structure, direction and implementation of social investments in order to achieve the maximum beneficial effect and ensure stable financial and economic activity of PJSC "Ukrzaliznytsia" in the near and future.

The effective mechanism of management of social investment activity of PJSC "Ukrzaliznytsia" makes it possible to achieve the goals and solve the main tasks with the maximum speed, contributes to the effective implementation of specific functions of management of social investment activity, full and consistent practical implementation of which is the key to a reliable active investment policy of PJSC" Ukrzaliznytsia " and its effective economic activity.

Keywords: social investments, mechanism of social investment, railway transport, PJSC "Ukrzaliznytsia", the process of social investment

Постановка проблеми та ії зв'язки з науковими чи практичними завданнями. У сучасному світі людський, інтелектуальний і соціальний капітал стають основою багатства, визначають конкурентоспроможність економічних систем та є ключовим ресурсом іiі розвитку. В останні роки в Україні питання про соціальну відповідальність бізнесу постало особливо гостро, оскільки через низку причин держава сьогодні не в змозі забезпечити прийнятний рівень соціальної захищеності людей. Установлені мінімальні соціальні гарантії, нагальні соціальні проблеми не вирішуються, механізми соціальної допомоги показують свою неефективність. Отже, розвиток суспільства потребує уваги до соціального інвестування як до цілеспрямованого вкладення ресурсів у розвиток соціальної сфери, тобто сфери, де саме формується і нарощується людський, інтелектуальний i соціальний капітал. Соціальні інвестиції $є$ основним інструментом i важливою ознакою соціальної відповідальності на всіх рівнях, що здійснюються 3 метою одержання корисного суспільного ефекту в майбутньому.

Централізація управління залізничним транспортом призводить до того, що рух інвестиційних ресурсів усередині галузі носить централізованоперерозподільний характер, відображаючись на специфіці механізму формування i розподілу інвестиційних ресурсів. Наслідками дії такого механізму є: по-перше, обмежена можливість залучення приватних інвестицій, у тому числі іноземних інвесторів; по-друге, непрозорість фінансово-інвестиційної діяльності; по-третє, розподільчий механізм ресурсів може не враховувати повною мірою інвестиційні інтереси всіх залізниць. Крім цього, компенсаційний механізм $\epsilon$ непрацездатним, участь місцевих бюджетів у формуванні інвестиційних програм ілюзійною, як і фінансування за рахунок держбюджету.

Вісник економіки транспорту і промисловості № 64, 2018 
3 урахуванням специфіки функціонування ПАТ «Укрзалізниця» до джерел формування соціальних інвестиційних ресурсів відносять: власні (частка прибутку, амортизаційні відрахування, виручка від реалізації основних засобів, частка оборотних коштів, страхова сума відшкодування збитків), позикові (кредити комерційних банків, емісія облігацій, цільовий державний кредит, фінансовий лізинг), залучені (емісія акцій, вклади інвесторів, цільова безоплатна передача коштів державними органами).

Аналіз останніх досліджень $\boldsymbol{i}$ публікацій. Теоретичні підходи до визначення сутності соціального інвестування та механізму його набули достатньо широкого висвітлення в останні роки, паралельно 3 дослідженнями механізмів реалізації корпоративної соціальної відповідальності. Зокрема, на нашу думку, слід виокремити роботи С.В. Туркіна [2], А.В. Маркова [5], Н.Я. Яневич [7], Д. Шейман, К. Смирнова [8] та ін. Окремі теоретичні аспекти механізму забезпечення соціальної відповідальності бізнесу й особливостей формування системи соціальної відповідальності на підприємствах в умовах глобальної економіки розглянуто у працях С. Панченко, В. Диканя, Ю. Боровика, В. Компанієць, В. Зубенко, I. Токмакової, О. Маковоз, О. Полякової, Ю. Уткіної, О. Шраменко [3, $4,6]$.

Виділення невирімених частин загальної проблеми. 3 проблемою соціальних інвестицій пов'язане широке коло нерозв'язаних питань. Це не лише інвестування в освіту, охорону здоров'я, в поліпшення умов проживання та культурний розвиток особистості, а й сучасний стан системи освіти, охорони здоров'я тощо. Питання соціального інвестування $\epsilon$ об'єктом дослідження різноманітних суспільних та міжнародних організацій, спеціалізованих науково-дослідних інститутів. Однак, на жаль, проблематика дослідження механізмів соціального інвестування тільки починає набувати широкого висвітлення у наукових роботах.
Формування цілей статті

(постановка завдання). Саме тому метою статті $\epsilon$ розбудова механізму соціального інвестування ПАТ «Укрзалізниця».

Виклад основного матеріалу дослідження. На сучасному етапі розвитку соціального інвестування ПАТ «Укрзалізниця» соціальні інвестиції товариства в більшій мірі спрямовані на реалізацію внутрішніх програм, метою яких $\epsilon$ розвиток власного людського капіталу, ресурсозбереження та задоволення потреб співробітників [6]. Левову частку серед них посідають програми «базового» рівня соціального інвестування, які охоплюють сплату внесків за програмами загальнообов'язкового соціального та недержавного медичного страхування, видатки на забезпечення належних умов праці, підвищення кваліфікації та освітні програми для співробітників. Поряд з цим можна виділити соціальні інвестиції «розширеного» або корпоративного рівня, що охоплюють забезпечення працівників не лише адекватними умовами праці, а й належними умовами життя (профілактичне лікування та сприяння фізичному розвитку, будівництво житла, розвиток соціальної інфраструктури, забезпечення повноцінного відпочинку та дозвілля) [5]. Вищий рівень соціального інвестування передбачає реалізацію соціальних програм, що виходять за межі підприємства та спрямовані на вирішення проблем місцевої громади, території, на якій розташовано підприємство, або проблем регіонального та державного значення.

При розбудові механізму соціального інвестування ПАТ «Укрзалізниця» важливо:

- по-перше, щоб процес соціального інвестування був децентралізованим, тобто програми, які реалізують відокремлені структурні підрозділи, повинні ними ж розроблятися;

- по-друге, розробка та реалізація програм соціального інвестування повинна сприяти досягненню як стратегічних цілей компанії, так i тактичних цілей відокремлених структурних підрозділів; 
- по-трете, здійснення соціальних інвестицій повинно сприяти не лише сталому розвитку громад, а й створенню умов для досягнення позитивних фінансовоекономічних результатів відокремлених структурних підрозділів, відповідно, i компанії у довгостроковій перспективі.

Процес соціального інвестування ПАТ «Укрзалізниця» $є$ динамічним процесом реалізації взаємовідносин між суб'єктами та об'єктами інвестування, який покликаний збалансувати інтереси корпоративного та соціального секторів економіки. Особливістю реалізації цих відносин для товариства $\epsilon$ те, що підприємства - відокремлені структурні підрозділи ПАТ «Укрзалізниця» узгоджують інтереси із представниками громад, на території яких вони функціонують, а головна компанія реалізуючи корпоративну соціальну відповідальність, повинна сприяти досягненню задекларованих на рівні держави загальносуспільних інтересів [2]. Водночас, така їх діяльність має бути спрямована на досягнення цілей як окремих підприємств, так і компанії загалом. Відносини між суб'єктами та об'єктами, які виникають у процесі соціального інвестування, демонструють їх (соціальних інвестицій) економічну суть. Тобто механізм здійснення капіталовкладень в об'єкти соціальної сфери передбачає виникнення відповідного соціального ефекту, 3 одного боку, та дотримання взаємних зобов'язань перед суб'єктами інвестування - 3 іншого. Досягнення мети соціального інвестування $\epsilon$ особливо важливим і для суб'єктів інвестування, оскільки крім отримання значного соціального ефекту (наприклад, покращення добробуту місцевої громади), це ще й підвищує їх інвестиційну привабливість, тобто є передумовою сталого розвитку.

Механізм управління соціальною інвестиційною

діяльністю ПАТ «Укрзалізниця», на нашу думку, охоплює традиційні компоненти системи управління, серед яких планування, аналіз, організація, контроль, оцінка, мотивація соціальної інвестиційної діяльності. Крім того, включає специфічні набори інструментарію залучення інвестицій, відрізняється моделями розподілу інвестиційних ресурсів, напрямками активізації інвестиційної діяльності та чинниками забезпечення інвестиційної привабливості.

Він визначається як сукупність організаційно-економічних форм і методів, інструментів i важелів дії на соціальну інвестиційну діяльність, взаємопов'язаних в єдиний механізм, що припускає мотиваційне, правове, ресурсне і методичне забезпечення, котрий дозволяє визначити обсяг, структуру, напрями i реалізацію соціальних інвестицій 3 метою досягнення максимального корисного ефекту i забезпечення стабільної фінансовогосподарської діяльності ПАТ «Укрзалізниця» в найближчій i подальшій перспективі.

Слід зазначити, що даний механізм $\epsilon$ складовою фінансово-економічного системи галузі, рушійним елементом останнього $€$ інвестиційна галузева політика, котра сформована у відповідності із засадами розвитку економічної системи країни та реформ, що його супроводжують [7].

Основні складові механізму управління соціальною інвестиційною діяльністю представлено на рис. 1.

$\begin{array}{cccc} & \text { Забезпечення } & \text { сталої } & \text { роботи } \\ \text { ПАТ } & \text { «крзалізниця» } & \text { певною } & \text { мірою }\end{array}$ залежить від своєчасного та достатнього забезпечення соціальними інвестиційними ресурсами. До основних джерел фінансування соціальних інвестицій на залізничному транспорті належать: власні кошти залізниць і структурних підрозділів (прибуток, амортизаційні відрахування); кошти державного і місцевого бюджетів, які можуть надаватися на зворотній та незворотній основі, а також у вигляді податкового кредиту, дотацій, субсидій або компенсації частки банківського відсотка за наданими кредитами; кошти позабюджетних фондів; кредити банків та інших фінансових установ; облігаційні позики; кошти іноземних інвесторів; лізинг [4].

Вісник економіки транспорту і промисловості № 64, 2018 


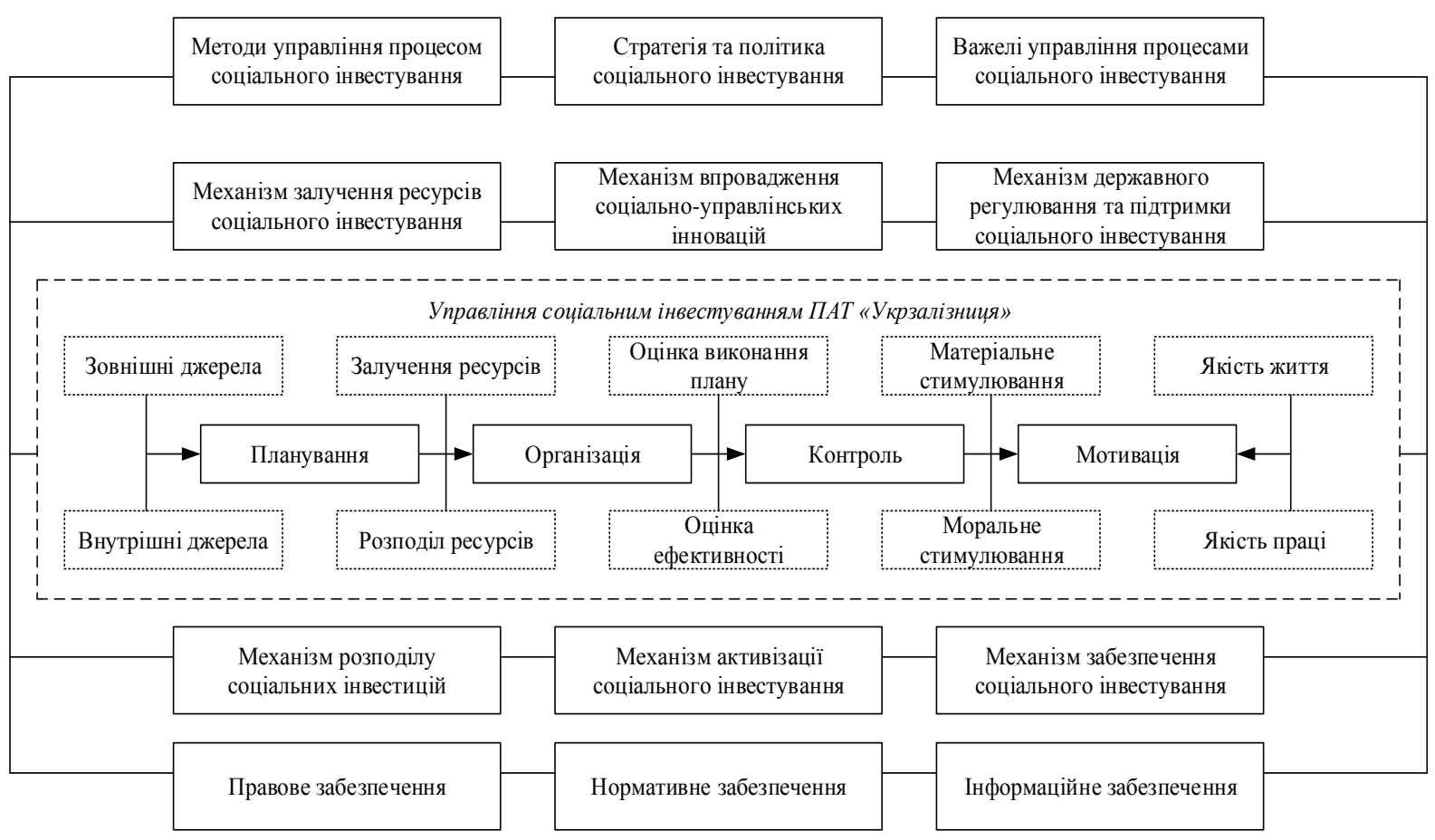

Рис. 1. Механізм управління соиіальною інвестиційною діяльністю ПАТ «Укрзалізниия»

Форми державної

передбачають: надання субвенцій, бюджетних позик; реалізації заходів щодо розвитку та захисту економічної конкуренції; реалізація стратегії роздержавлення і приватизації власності; проведення політики ціноутворення тощо.

Важливою особливістю соціального інвестування ПАТ «Укрзалізниця» $\epsilon$ змішаний метод інвестування, певний вид диверсифікації джерел, поєднання різних форм фінансування проектів тощо. В цілому всі методи інвестування можна поділити як такі, де використовуються посередники (держава, приватні інвестори, змішане фінансування) та не використовуються (повне самоінвестування) [7]. Останні внаслідок браку власних фінансових ресурсів залізницями використовуються обмежено. Негативно впливає на соціальну інвестиційну діяльність існуюча централізація управління залізничним транспортом, яка призводить до того, що рух інвестиційних потоків усередині залізничної системи також носить централізовано-перерозподільчий характер і диктує специфічний механізм формування й розподілу інвестиційних ресурсів. Основними недоліками такої схеми є: недостатня фінансова прозорість фінансовоінвестиційної діяльності; обмежені можливості залучення приватних інвестицій; дискримінаційне відношення при розподілі інвестиційних ресурсів. Для активізації соціальних інвестиційних процесів ПАТ «Укрзалізниця» вирішальне значення мають такі заходи: розвиток механізмів державних гарантій, збільшення обсягів державних інвестицій; подальше удосконалення програмних завдань всебічної структурної перебудови економіки галузі на перспективу; здійснення координації напрямків діяльності інвесторів та застосування нових ринкових схем та механізмів їхньої участі в інвестуванні інноваційних програм та проектів галузі; залучення до фінансування інноваційних розробок, орієнтованих на створення перспективних об'єктів залізничного транспорту, впровадницько-інноваційних фірм - фірм ризикового (венчурного) капіталу, як нового для галузі джерела інвестиційних ресурсів; розробка 
привабливих для потенційних інвесторів інноваційних проектів, впровадження маркетингових підходів до пошуку та залученню інвестиційних ресурсів.

Важливим фактором отримання додаткових соціальних інвестицій $\epsilon$ підвищення інвестиційної привабливості підприємств залізничної галузі. Для цього необхідно збільшити їх капіталізацію; створити стабільну та спрямовану для інвесторів законодавчу базу; підвищити інвестиційний рейтинг; забезпечити рентабельну діяльність підприємств залізничного транспорту.

Висновки даного досліджсення $i$ перспективи подальших робіт у цьому напрямку. Таким чином, на нашу думку, ефективний механізм управління соціальною інвестиційною діяльності ПАТ «Укрзалізниця» дає змогу 3 максимальною швидкістю досягти поставлених цілей та вирішити основні завдання, сприяє результативному виконанню конкретних функцій управління соціальною інвестиційною діяльністю, повна і послідовна практична реалізація яких $\epsilon$ надійною запорукою активної інвестиційної політики ПАТ «Укрзалізниця» та його результативної господарської діяльності.

Для вирішення проблем соціального інвестування необхідне удосконалення самого механізму інвестиційної діяльності в галузі - всіх його складових (в тому числі інституцій), що приведе до його спрощення, здешевлення в утриманні, прозорості діяльності, маневреності, розбюрократизації. Крім того, необхідний перехід механізму соціального інвестування в більш гнучку, мобільну форму функціонування, що сприятиме його відповідності сучасним умовам господарювання.

\section{ПЕРЕЛІК ВИКОРИСТАНИХ ДЖЕРЕЛ}

1. Охріменко, О.О. Соціальна відповідальність [Текст]: навч. посіб. // О.О. Охріменко, Т.В. Іванова. - К.: НТУУ «КПІ», 2015. - $180 \mathrm{c}$.

2. Туркин С.В. Зачем бизнесу социальная ответственность? [Электронный pecypc] / С.В. Туркин // Корпоративный менеджмент. - Режим доступа: http://www.cfin.ru/

3. Дикань, В.Л. Етичні основи бізнесу [Текст]: підручник / В.Л. Дикань, В.В. Компанієць, О.М. Полякова. - Харків: УкрДАЗТ, 2012. - $316 \mathrm{c.}$

4. Дикань, В.Л. Стратегічне управління [Текст]: навч. посіб./ В.Л. Дикань, В.О. Зубенко, О.В. Маковоз, I.В. Токмакова, О.В. Шраменко - К.: «Центр учбової літератури», 2013. - 272 с.

5. Марков А.В. Альтруисты и паразиты / А.В. Марков // Наука в фокусе. М.: Вокруг света, 2012. - №3. - С. 21-26.

6. Панченко, С.В. Підприємництво [Текст]: підручник / С.В. Панченко, В.Л. Дикань, О.В. Шраменко, О.М. Полякова, Ю.М. Уткіна. - Х.: УкрдУЗТ, 2016. - Ч.2. - $241 \mathrm{c}$.

7. Яневич Н.Я. Соціальні інвестиції: сутність i класифікація [Електронний pecypc] / Н.Я. Яневич // Lviv Polytechnic National University Institutional Repository. Режим доступу: http://ena.lp.edu.ua/ bitstream/ntb/11337/1/26.pdf

8. Шейман Д. Социально ответственное инвестирование. Опыт развитых стран [Электронный ресурс] / Д. Шейман, К. Смирнова // Cloudwatcher. Лаборатория социальных инноваций. Режим доступа: http://www.cloudwatcher.ru/ userfiles/investsite.pdf.

9. Report on Socially Responsible Investing Trends in the United States. 2017 [Электронный ресурс] // The Forum for Sustainable and Responsible Investments. Режим доступу: http://www.ussif.org /files/Publications/10_Trends_Exec_Summary. pdf 